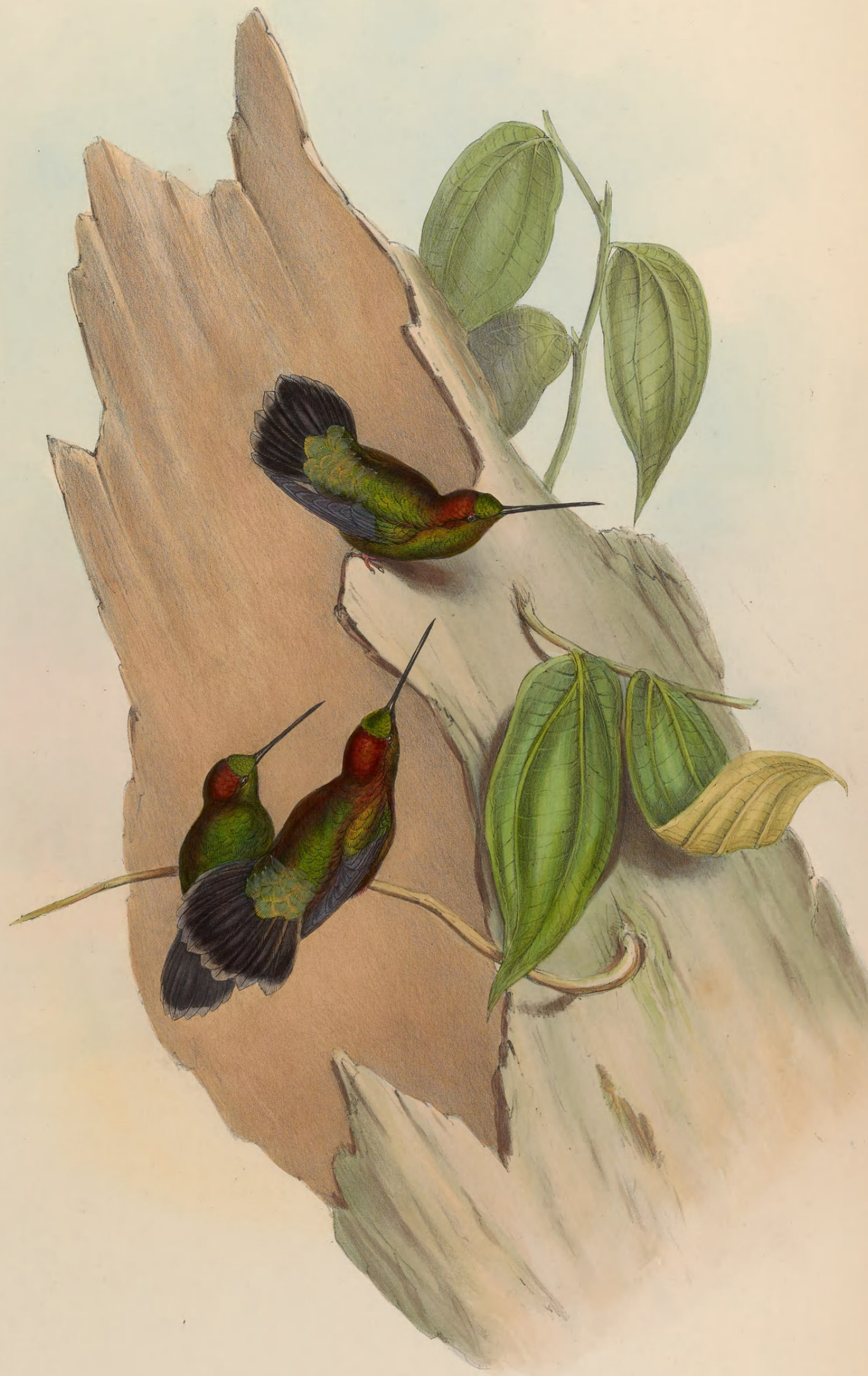

DDRIFERA I.IDOYUIE 


\section{DORIFERA LUDOVICI}

\section{Green-fronted Lance-Bill.}

Trochilus Ludovicia, Bourc. et Muls. in Ann. de la Soc. Roy. d'Agric. \&c. de Lyon, 1847, p. 136.

Mellisuga Ludovicia, Gray and Mitch. Gen. of Birds, vol. i. p. 112, Mellisuga, sp. 19.

Dorifera ludovicia, Bonap. Consp. Gen. Av., p. 68, Dorifera, sp. 1.

$\mathrm{N}_{\text {aturalists }}$ often assume the privilege of honouring individuals by naming remarkable species after them, and although this practice is by no means to be commended, it is one which may readily be excused when exercised in favour of those whose names are favourably known in the annals of science; in the present instance it has been employed with singular appropriateness to do honour, through his wife, to M. Isidore Geoffroy Saint-Hilaire, whose fame as a scientific naturalist is familiar to every one.

The Dorifera Ludovicice is remarkable for its short and robust body, the length of its wings, and the straight, sharp, needle-like form of its bill, features in its structure which doubtless in some way modify its habits; probably the peculiar shape of the bill is especially fitted for procuring its insect food from the smaller kinds of tubular flowers, or from among the prickly spines of the Cacti, tribes of plants which abound in the country frequented by the bird. Like many other rarities, this species is a native of New Grenada, and particularly the neighbourhood of Santa Fé de Bogota, from whence alone I believe up to this time specimens have been received; but whether it is a native of the upland or lowland districts of the country is unknown.

All the examples that have come under my notice have been alike in colour, which induces me to believe that there is no difference in the colouring of the sexes; but this of course is uncertain.

Forehead luminous metallic green; crown of the head and nape coppery bronze; back and wing-coverts dark bronzy green, passing into bluish green on the upper tail-coverts; wings purplish brown; tail black, tipped with brownish grey, slightly on the two middle and largely on the lateral feathers; under surface dark bronzy green with a tinge of grey; under tail-coverts grey, with reflexions of bluish green; bill black; feet fleshy-brown.

The figures are of the size of life. 


\section{$2 \mathrm{BHL}$ Biodiversity Heritage Library}

Gould, John. 1853. "Doryfera ludoviciæ, Green-fronted Lance-Bill. [PI. 88]." A monograph of the Trochilidae, or family of humming-birds 2, https://doi.org/10.5962/p.316897.

View This Item Online: https://www.biodiversitylibrary.org/item/108332

DOI: https://doi.org/10.5962/p.316897

Permalink: https://www.biodiversitylibrary.org/partpdf/316897

\section{Holding Institution}

Smithsonian Libraries

\section{Sponsored by}

Smithsonian Institution Libraries

\section{Copyright \& Reuse}

Copyright Status: NOT_IN_COPYRIGHT

This document was created from content at the Biodiversity Heritage Library, the world's largest open access digital library for biodiversity literature and archives. Visit BHL at https://www.biodiversitylibrary.org. 